\title{
Anti-Reflexivity and Climate Change Skepticism in the US General Public
}

\author{
Aaron M. McCright ${ }^{1}$ \\ Lyman Briggs College and Department of Sociology \\ Michigan State University, Michigan, United States
}

\section{Abstract}

The leading theoretical explanation for the mobilization of organized climate change denial is the Anti-Reflexivity Thesis, which characterizes the climate change denial countermovement as a collective force defending the industrial capitalist system. In this study, I demonstrate that the Anti-Reflexivity Thesis also provides theoretical purchase for explaining patterns of climate change skepticism among regular citizens. Analyzing nationally representative survey data from multiple waves of the University of Texas Energy Poll, I examine key predictors of climate change skepticism within the US general public. Identification with or trust in groups representing the industrial capitalist system increases the likelihood of climate change skepticism. Also, identification with or trust in groups representing forces of reflexivity (e.g., the environmental movement and scientific community) decreases the likelihood of such skepticism. Further, this study finds that climate change skeptics report policy preferences, voting intentions, and behavioral intentions generally supportive of the existing fossil fuels-based industrial capitalist system.

Keywords: anti-reflexivity thesis, climate change skepticism, policy preferences, voting intentions, behavioral intentions

\section{Introduction}

Over the last three decades, climate change has become successfully defined as a serious global problem deserving ameliorative action, due largely to the actions of the scientific community and environmental movement. During much of this same time, a climate change denial countermovement has mobilized to deny the reality and seriousness of climate change as a social problem by opposing the claims of the scientific community and environmental movement (e.g., Dunlap \& McCright, 2016). Much scholarship analyzes the strategies,

1 Author contact: mccright@msu.edu. 
techniques, and effectiveness of key components of this US-based climate change denial countermovement: fossil fuels (and other) industry organizations (e.g., Freudenburg, Gramling, \& Davidson, 2008; Layzer, 2007), conservative think tanks (e.g., Dunlap \& Jacques, 2013; McCright \& Dunlap, 2000, 2003; Oreskes \& Conway, 2010), contrarian scientists (e.g., Lahsen, 2008; McCright, 2007), and Republican politicians (e.g., McCright \& Dunlap, 2003, 2010). Recent work confirms the results of earlier studies and documents the evolving funding and organizational structure of this countermovement (e.g., Boussalis \& Coan, 2016; Brulle, 2014; Farrell, 2016a, 2016b).

The leading theoretical explanation for this mobilization of organized climate change denial is the Anti-Reflexivity Thesis (e.g., McCright \& Dunlap, 2010), which characterizes the climate change denial countermovement as a collective force defending the industrial capitalist system against claims that the system causes serious problems. In this paper, I argue that the Anti-Reflexivity Thesis also may provide insights for understanding the patterns of climate change skepticism $^{2}$ within the general public. Analyzing nationally representative survey data from multiple waves of the University of Texas Energy Poll, I test hypotheses derived from the Anti-Reflexivity Thesis to explain key predictors of climate change skepticism within the US general public. Further, since few studies focus on the attitudes and behaviors of climate change skeptics, I also examine how climate change skepticism is related to energy-related policy preferences, voting intentions, and behavioral intentions.

Briefly, this paper makes the following contributions. First, this study extends an emerging theoretical framework in environmental sociology by demonstrating the efficacy of the Anti-Reflexivity Thesis for explaining the dynamics of climate change skepticism in the general public. In the process, this study integrates key theoretical insights into the evolving scholarship on climate change skepticism. Second, the analyses determine the extent to which key Anti-Reflexivity Thesis variables (i.e., trust in and/or identification with forces of reflexivity or antireflexivity) influence climate change skepticism independent of the effect of political orientation. This may provide theoretical guidance for understanding

\footnotetext{
2 In this paper, I use "climate change denial" when discussing the individuals and organizations in the organized countermovement to challenge the reality and seriousness of anthropogenic climate change. I use "climate change skepticism" when discussing members of the general public who do not believe the scientific claims about climate change but who otherwise are not likely involved actively in the climate change denial countermovement. In my literature review of studies reporting the results of general public surveys, I use "skepticism" for what other scholars variously term "rejecting the science," "denial," "skepticism," "contrarianism," or "naysaying." I do recognize that using "skepticism" in this way is inconsistent with how philosophers and sociologists of science historically have used the term, especially when discussing the institution of science (e.g., Merton, 1938). Yet, social scientists who study climate change lack a more accurate term between "skepticism" and "denial." It seems prudent to reserve use of the term "denial" to those individuals and organizations actively challenging the reality and seriousness of anthropogenic climate change and apply the term "skepticism" to regular members of the general public who simply report views in opposition to the scientific community.
} 
climate change skepticism in those countries where climate change is less politicized and skepticism is less aligned with political orientation. Third, this study is one of the first to examine how climate change skepticism is related to other environmentally consequential decisions.

In the next section, I review those studies that specifically examine climate change skepticism among regular citizens. I then explain the key arguments of the Anti-Reflexivity Thesis, deriving insights for explaining citizens' climate change skepticism. After describing the dataset and the variables used in the study, I present and discuss the results of my analyses. I close with a brief discussion of potential avenues for future research.

\section{Survey research on climate change skepticism}

The last 15 years have seen the emergence of a body of studies examining the patterns of climate change skepticism via survey research. This literature is still developing and remains characterized by a range of approaches and analytical techniques and, more consequentially, diversity in the operationalization of climate change skepticism. Nevertheless, a few clear patterns can be identified. In this section, I first describe the nature of these studies before summarizing their most robust empirical results.

Most of the studies in this emerging literature examine the predictors of climate change skepticism (e.g., Evans \& Feng, 2013; Leviston \& Walker, 2012; Poortinga et al., 2011), though a few treat climate change skepticism as a predictor variable (e.g., Capstick \& Pidgeon, 2014; Engels et al., 2013; Smith \& Leiserowitz, 2012). While some studies use small, non-representative samples, ${ }^{3}$ most utilize large, nationally representative samples from the United States (e.g., Feldman et al., 2012; Hamilton, 2012; Leiserowitz et al., 2012; McCright \& Dunlap, 2011a), Australia (e.g., Leviston \& Walker, 2012; Leviston et al., 2013; Lewandowsky, Gignac, \& Oberauer, 2013), Britain (e.g., Clements, 2012; Poortinga et al., 2011), or Germany (e.g., Engels et al., 2013).

Earlier work identifies four key dimensions of climate change skepticism: believing that the Earth is not warming and climate change is not happening (trend skepticism); believing that human activities are not causing climate change (attribution skepticism); believing that climate change will not have significant negative impacts (impact skepticism); and believing that there

3 These studies using small, non-representative samples examine residents of a western Canadian city (Heath \& Gifford, 2006), residents of a few British counties (Whitmarsh, 2011), the UK general public (Capstick \& Pidgeon, 2014), residents of an Australian state (Lo, 2014), Australian adults (Hobson \& Niemeyer, 2013), residents of a Swedish city (Häkkinen \& Akrami, 2014), and visitors of climate blogs from multiple countries (Lewandowsky, Oberauer, \& Gignac, 2013). 
is no strong scientific agreement on the reality and human cause of climate change (consensus skepticism) (e.g., McCright \& Dunlap, 2000; McCright, Dunlap, \& Xiao, 2013; Rahmstorf, 2004). Most of the studies in this literature operationalize climate change skepticism directly via single-item or composite measures. ${ }^{4}$ These studies can be classified according to the dimensions of skepticism they measure (even as they may also include items that do not easily fit into the following categories):

- trend skepticism only (e.g., Hmielowski et al., 2014; Leviston et al., 2013);

- trend and attribution skepticism only (e.g., Leviston \& Walker, 2012);

- trend, attribution, and impact skepticism only (e.g., Capstick \& Pidgeon, 2014; Clements, 2012; Heath \& Gifford, 2006; Leiserowitz et al., 2012; Lewandowsky, Oberauer, \& Gignac, 2013; Lewandowsky, Gignac, \& Oberauer, 2013; Lo, 2014; Whitmarsh, 2011); and

- trend, attribution, impact, and consensus skepticism (Engels et al., 2013; Feldman et al., 2012; Häkkinen \& Akrami, 2014; McCright \& Dunlap, 201la; Poortinga et al., 2011).

Few of the studies using nationally representative data provide descriptive statistics to allow comparison of the spread of climate change skepticism across countries and over time. Further, those studies that do report such statistics often utilize different measures of the various dimensions of climate change skepticism. Nevertheless, four studies report the results of analyses with nationally representative survey data from 2010 or 2011, allowing for at least a rough comparison: 2011 Germany (Engels et al., 2013), 2010 Australia (Leviston \& Walker, 2012), 2010 United States (McCright \& Dunlap, 2011a), and 2010 Britain (Poortinga et al., 2011). The sole study examining climate change skepticism over time with multiple years of data finds that all dimensions of climate change skepticism increased in the US general public between 2001 and 2010 (McCright \& Dunlap, 2011a).

With the exception of Germany where all forms of skepticism are low-only about $7 \%$ of Germans are trend skeptics, $7 \%$ are attribution skeptics, $5 \%$ are impact skeptics, and $8 \%$ are consensus skeptics-(Engels et al., 2013), trend skepticism seems to be less prevalent than does attribution, impact, or consensus skepticism in Australia, Britain, and the United States. Nearly 19\% of Americans believe that global warming will never happen (McCright \& Dunlap, 2011a), while $15 \%$ of the British public does not think the world's climate is changing

\footnotetext{
4 Three studies operationalize climate change skepticism indirectly: giving factually incorrect answers to specific questions about climate change (Hamilton, 2012); providing "naysayer affective imagery" in responses to open-ended questions (Smith \& Leiserowitz, 2012); and believing that environmental scientists don't understand the causes of global warming very well and should have little influence in deciding what to do about global warming (Evans \& Feng, 2013).
} 
(Poortinga et al., 2011), and between 6\% and 17\% of Australians (depending upon the measure) are trend skeptics (Leviston \& Walker, 2012). Nearly $46 \%$ of Americans (McCright \& Dunlap, 2011a), 18\% of the British public (Poortinga et al., 2011), and about $40 \%$ of Australians (Leviston \& Walker, 2012) attribute global warming solely or primarily to natural processes. About $48 \%$ of Americans (McCright \& Dunlap, 201la) and 40\% of the British public (Poortinga et al., 2011) believe that the seriousness of global warming is exaggerated. Finally, about $48 \%$ of Americans (McCright \& Dunlap, 2011a) but only $21 \%$ of the British public (Poortinga et al., 2011) believe there is no scientific consensus on climate change.

Several clear patterns emerge from those studies examining predictors of climate change skepticism in the general publics of advanced industrial countries. By far the most robust predictor of climate change skepticism is political orientation, whereby ideological conservatives (Clements, 2012; Evans \& Feng, 2013; Häkkinen \& Akrami, 2014; Leiserowitz et al., 2012; Lewandowsky, Gignac, \& Oberauer, 2013; McCright \& Dunlap, 2011a) and supporters/members of conservative political parties (Campbell \& Kay, 2014; Evans \& Feng, 2013; Feldman et al., 2012; Hamilton, 2012; Leiserowitz et al., 2012; Leviston \& Walker, 2012; McCright \& Dunlap, 2011a; Poortinga et al., 2011; Whitmarsh, 2011) are more likely to report climate change skepticism than are their liberal counterparts. Several studies simply do not include a measure of political orientation (Capstick \& Pidgeon, 2014; Cho et al., 2011; Engels et al., 2013; Heath \& Gifford, 2006; Leviston et al., 2013; Lewandowsky, Oberauer, \& Gignac, 2013; Lo, 2014). Yet, all survey studies that do include either political ideology or party identification or both find political orientation to be a significant predictor - typically one of the strongest predictors. Related to political orientation, other studies find that espousing a free market ideology (Campbell \& Kay, 2014; Heath \& Gifford, 2006; Lewandowsky, Gignac, \& Oberauer, 2013; Lewandowsky, Oberauer, \& Gignac, 2013), strongly valuing private property rights (Lo, 2014), strongly supporting hierarchies (Häkkinen \& Akrami, 2014), regularly viewing Fox News (Feldman et al., 2012), holding traditional values (Poortinga et al., 2011), and being a conservative Protestant (Evans \& Feng, 2013) are also associated with climate change skepticism.

The performance of social, demographic, and economic variables is less consistent, though some patterns have emerged. Several studies find that weak environmental beliefs (Engels et al., 2013; Feldman et al., 2012; Whitmarsh, 2011), weak environmental movement identity (McCright \& Dunlap, 2011a), or strong environmental apathy (Heath \& Gifford, 2006) are associated with climate change skepticism. Men report stronger climate change skepticism than do women (Clements, 2012; Feldman et al., 2012; Leviston \& Walker, 2012; McCright 
\& Dunlap, 2011a). ${ }^{5}$ Further, low socioeconomic status (education and income) is associated with climate change skepticism, but only in the United Kingdom (Clements, 2012; Poortinga et al., 2011; Whitmarsh, 2011). The remaining sociodemographic variables (e.g., age, religiosity, etc.) — when included in analyses at all - typically perform poorly or inconsistently in predicting climate change skepticism.

\section{The Anti-Reflexivity Thesis}

Reflexive Modernization Theory (e.g., Beck, 1992; Giddens, 1990; see also Rosa, Renn, \& McCright, 2014) characterizes the current era of late modernity as a distinct stage of advanced industrial society where institutions suffer from legitimacy crises brought on by their inability to effectively solve the ecological and technological problems of modernization. Reflexive modernization scholars argue that heightened reflexivity is a necessary precondition for getting past our current ecological and technological crises. They define reflexivity as a self-confrontation with the unintended and unanticipated consequences of modernity's industrial capitalist system. Two prominent forces of reflexivity, which promote such societal self-confrontation, are social movements and science (e.g., Beck, 1992; Giddens, 1990; Mol, 2000). Most notably, environmental activism and those scientific fields that examine the ecological and human health impacts of economic activities and new technologies - what Schnaiberg (1980) terms "impact science"6 - attempt to force societal recognition of, and action on, our major ecological and technological crises.

During these times of fundamental societal change, other sectors of societyfor ideological and/or material reasons - mobilize to challenge the shift toward societal self-confrontation. Gleeson (2000) refers to this as a mobilization of "anti-reflexivity," because it attempts to defend the legitimacy of the industrial capitalist system against the open-ended transformation of reflexive modernization. More specifically, it directly opposes the forces of reflexivity that identify problems caused by the industrial capitalist system and urge government action to deal with them. Within the United States, recognizing and attempting to deal with major ecological crises has provoked significant antireflexivity since the late 1980s (Jacques, 2006; McCright, Xiao, \& Dunlap, 2014).

\footnotetext{
5 McCright \& Dunlap (2011a) document what they refer to as the "conservative white male" effect, whereby conservative white males are more likely to deny the reality and seriousness of climate change than are others in the general public.

6 "Impact science" stands in conceptual distinction from what Schnaiberg (1980) terms "production science," or scientific activities in service to economic production. While this abstract, analytical typology is theoretically powerful (e.g., McCright et al., 2013), it can often be quite difficult to empirically distinguish impact science and production science (e.g., Gould, 2015).
} 
The Anti-Reflexivity Thesis (McCright \& Dunlap, 2010) initially was developed to explain why certain sectors of advanced industrial society mobilized to defend the industrial capitalist system against the claims of social movements and the scientific community used to support calls for further governmental intervention into economic markets. While such opposition to governmental regulations has been a mainstay within industry and the conservative movement for many decades, a stronger version of anti-reflexivity emerged in the early 1990s. This was due largely to the rise of international environmentalism and environmental policy-making efforts to deal with global environmental problems (signaled by the 1992 Rio Earth Summit). Such an upsurge in reflexivity-culminating in the recognition of climate change as a significant global problem deserving substantial action - posed a much more fundamental challenge to the neoliberal expansionism of the industrial capitalist system than did earlier calls for more localized regulations to deal with air and water pollution (e.g., Foster et al., 2011; Jacques, 2006; McCright, Xiao, \& Dunlap, 2014).

McCright \& Dunlap (2010, 2011b) argue that the most prominent manifestation of anti-reflexivity in the United States is the mobilization of the American conservative movement and fossil fuels industry to deny the reality and seriousness of climate change. The last two decades in the United States have seen an enduring conflict between those defining climate change as real and characterizing it as problematic (the scientific community, environmental organizations, and many Democratic policymakers) and those defending the industrial capitalist system by challenging climate science and denying the dangerousness of climate change (fossil fuels industry organizations, conservative think tanks, contrarian scientists, and many Republican policymakers) (Brulle, 2014; Farrell, 2016a, 2016b; McCright \& Dunlap, 2000, 2003, 2010; Oreskes \& Conway, 2010).

While the Anti-Reflexivity Thesis has been used primarily to explain organized climate change denial activism (McCright \& Dunlap, 2010), it has been extended to explain climate change skepticism among self-identified conservatives and Republicans in the US general public (McCright et al., 2016; McCright \& Dunlap, $2011 \mathrm{~b}$ ) and the ideological divide on trust in science within the US general public (McCright et al., 2013). I continue this line of scholarship by deriving key insights from the Anti-Reflexivity Thesis to explain broader patterns of climate change skepticism within the US general public. I limit this discussion to those general theoretical expectations and corresponding specific hypotheses that can be tested with the data used in this study.

Briefly, the Anti-Reflexivity Thesis expects that identification with, support for, or trust in groups representing or defending the industrial capitalist system increases the likelihood of skepticism that the system is causing significant problems necessitating governmental action. Such groups include, among others, 
specific corporations (e.g., ExxonMobil), industry associations (e.g., American Petroleum Institute), conservative movement organizations (e.g., think tanks or foundations), and political parties (e.g., Republican Party) whose creeds espouse and actions embody defense of the industrial capitalist system and opposition to governmental regulations. ${ }^{7}$ The dataset in this study allows an empirical test of the following hypotheses.

Trust in groups representing the industrial capitalist system increases the likelihood of skepticism of the reality and human cause of climate change. $(\mathrm{H1})$

Identification with the Republican Party increases the likelihood of skepticism of the reality and human cause of climate change. (H2)

Also, the Anti-Reflexivity Thesis expects that identification with, support for, or trust in groups representing or defending forces of reflexivity decreases the likelihood of skepticism that the system is causing significant problems necessitating governmental action. Such groups include, among others, specific environmental movement organizations (e.g., Sierra Club) or the environmental movement more generally, the scientific community in general or specific science advocacy organizations (e.g., Union of Concerned Scientists), and political parties (e.g., Democratic Party) that accept the need for-and even advocate the use of - governmental regulations to solve problems created by the industrial capitalist system. ${ }^{8}$ The dataset in this study allows an empirical test of the following hypotheses.

Trust in groups representing forces of reflexivity decreases the likelihood of skepticism of the reality and human cause of climate change. (H3)

Identification with the environmental movement decreases the likelihood of skepticism of the reality and human cause of climate change. (H4)

Identification with the Democratic Party decreases the likelihood of skepticism of the reality and human cause of climate change. (H5)

In addition to testing these hypotheses, this dataset also allows investigation of how climate change skepticism relates to energy-related policy preferences, voting intentions, and behavioral intentions. This is significant since, other than Engel et al.'s (2013) study of German adults, scholars have not examined how energy-related attitudes and behaviors are related to climate change

$7 \quad$ This provides theoretical purchase for explaining why identification with the Republican Party (or other Right-leaning parties or conservative ideology more generally) is the most consistent predictor of climate change skepticism in the literature (e.g., Evans \& Feng, 2013; Feldman et al., 2012; Hamilton, 2012; McCright \& Dunlap, 2011b).

8 This helps explain why several studies find that climate change skepticism is more likely among those with low or no identification with environmentalism (e.g., Heath \& Gifford, 2006; McCright \& Dunlap, 2011a; Whitmarsh, 2011). 
skepticism. The analyses below specifically help fill this important gap and improve our understanding of the extent to which climate change skepticism in the US general public matters more generally.

\section{The study}

Data for this study come from the University of Texas at Austin Energy Poll, which is designed and managed by the Energy Management and Innovation Center of the McCombs School of Business. Since 2011, this biannual survey includes both recurring questions about energy priorities, policies, and behaviors and one-time questions about specific energy issues. Indeed, the University of Texas Energy Poll is the only ongoing nationally representative survey of Americans' energy views and behaviors. All waves, administered online in March and September, have independent samples of more than 2,000 US adults. Data weights are used to make each sample representative of the US adult population. ${ }^{9}$

I combined the repeated cross-sections from Wave 2 (March 2012) to Wave 7 (September 2014) into a pooled sample. ${ }^{10}$ The social, demographic, and political characteristics of this pooled sample are presented in Table 1. I used SPSS 19.0 to perform all statistical analyses with weighted data. Not all of the selected survey items were asked in each wave or of all the subjects in a wave, so the sample sizes vary across dependent variables and models. Table 2 contains the exact wording of the survey questions used to create all composite measures and outcome variables.

Table 1: Description of the pooled sample

\begin{tabular}{|l|c|}
\hline & \multicolumn{1}{|c|}{$\begin{array}{c}\text { Pooled sample } \\
\text { (N = 12,958) }\end{array}$} \\
\hline Gender (\% female) & 51.6 \\
\hline Age (\% aged 18-39) & 38.3 \\
\hline Race (\% white) & 79.0 \\
\hline Educational Attainment (\% at least bachelor's degree) & 30.1 \\
\hline Household Income (1-8 scale: "less than \$20K" to "\$200K and more”) & $4.11(2.17)$ \\
\hline Party Identification (N = 12,498) & \\
\hline \% Democrat & 40.3 \\
\hline \% Independent & 27.7 \\
\hline \% Republican & 32.0 \\
\hline
\end{tabular}

9 Additional details about the University of Texas Energy Poll can be found here: www.utenergypoll.com.

10 Wave 1 did not include the survey items used to create the climate change skepticism indicators. 


\begin{tabular}{|c|c|}
\hline & $\begin{array}{l}\text { Pooled sample } \\
\qquad(\mathrm{N}=12,958)\end{array}$ \\
\hline \multicolumn{2}{|l|}{ Religious Affiliation } \\
\hline \% Christian & 40.0 \\
\hline$\%$ non-Christian & 6.9 \\
\hline$\%$ non-religious & 53.1 \\
\hline Religiosity (1-4 scale: "not religious at all" to "very religious") & $2.70(1.01)$ \\
\hline Parental status (\% with child under 18 at home) & 27.8 \\
\hline Employment status (\% employed part- or full-time) & 47.4 \\
\hline \multicolumn{2}{|l|}{ Place of Residence } \\
\hline \% Rural & 24.0 \\
\hline$\%$ Suburban & 47.9 \\
\hline \% Urban & 28.1 \\
\hline
\end{tabular}

Note: Standard deviation is given in parentheses.

Two survey items were used to create the climate change skepticism indicators. Trend skepticism is measured by the following item: "Do you think global climate change is or is not occurring?" Trend skepticism is coded " 1 " for "is not occurring" and coded " 0 " for "is occurring" or "don't know." Approximately $18.2 \%$ of the pooled sample $(\mathrm{N}=12,958)$ are trend skeptics who do not think that climate change is occurring. ${ }^{11}$ While the survey does not contain a straightforward indicator of attribution skepticism as used in other studies, attribution skepticism can be reasonably approximated using the following item: "Please indicate the extent to which you think each of the following is a contributing factor in global climate change." The response categories range from "not at all a factor" $=1$ to "a very significant factor" $=5$. Among the options are "coal" and "oil." Attribution skepticism is coded " 1 " for those respondents who gave an answer of $0,1,2$, or 3 for both coal and oil and is coded " 0 " for all other respondents. Approximately $21.1 \%$ of the pooled sample $(\mathrm{N}=7,478)$ are attribution skeptics who believe that these fossil fuels are not significant contributors to climate change. ${ }^{12}$

11 This percentage is quite similar to that reported by McCright \& Dunlap (2011a). Briefly those authors report that $18.9 \%$ of the American public in 2010 were trend skeptics.

12 This percentage is much less than the $46 \%$ of Americans in 2010 identified as attribution skeptics by McCright \& Dunlap (2011a). The sizable difference between the 2010 percentage based on Gallup Poll data and the 2012-2014 percentage reported here is likely due to the different survey questions used to measure attribution skepticism. The item used here likely underestimates the actual prevalence of attribution skepticism in the US general public in 2012-2014. 
Anti-Reflexivity and Climate Change Skepticism in the US General Public

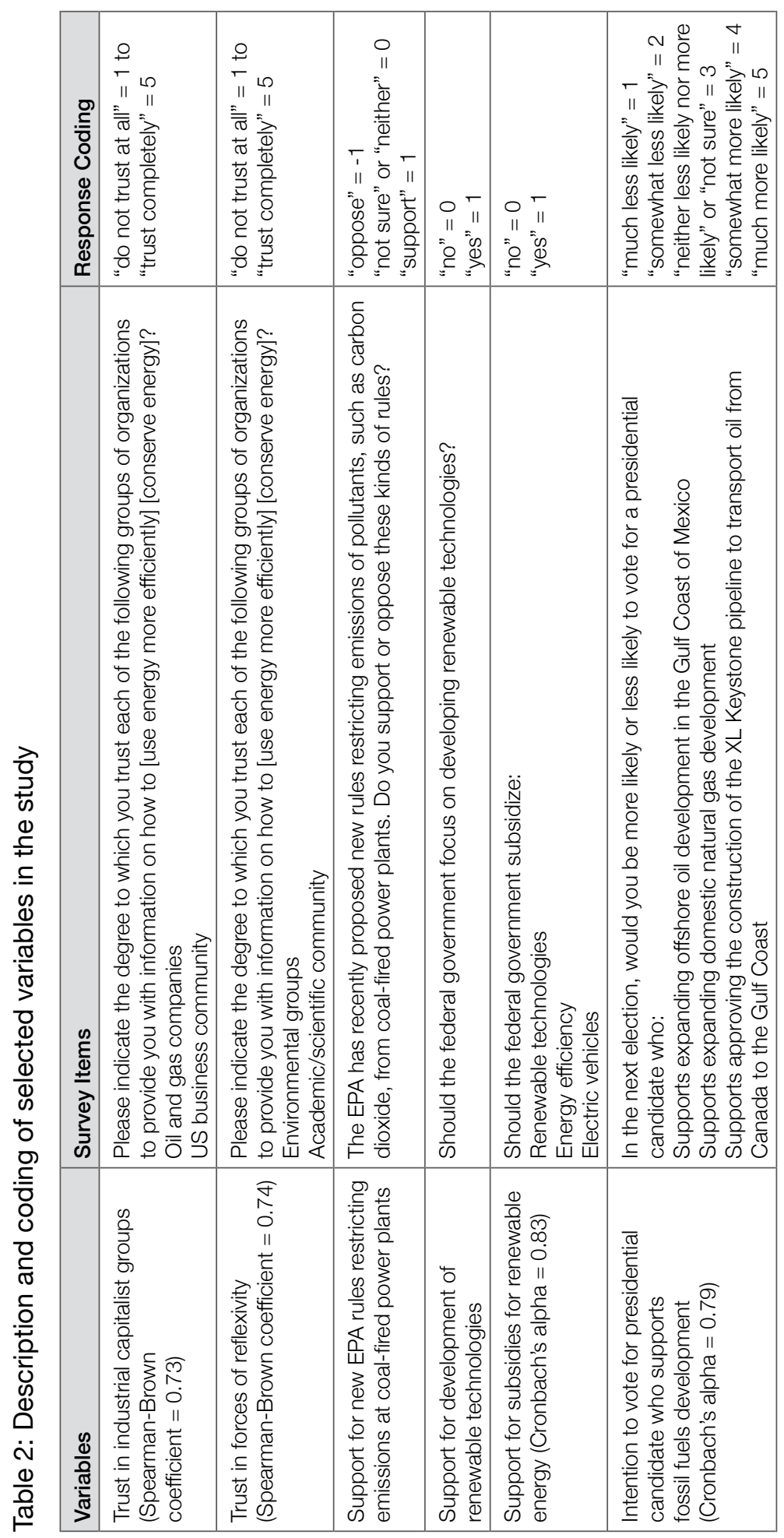




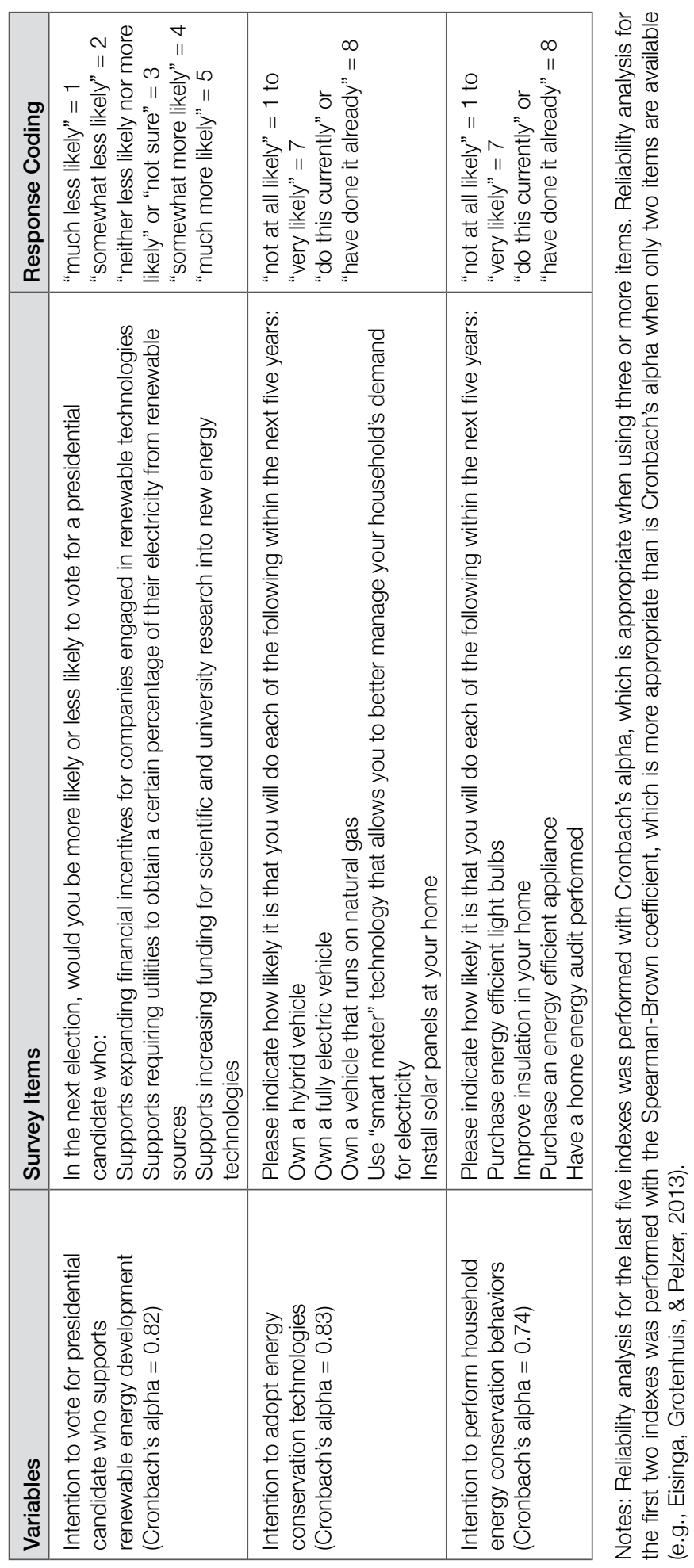


Two Anti-Reflexivity Thesis variables are composite measures. Briefly, respondents were asked how much they trust ("do not trust at all" = 1 to "trust completely" = 5) a few groups or organizations to provide them with information on how to use energy more efficiently or conserve energy. ${ }^{13}$ Trust in industrial capitalist groups (Spearman-Brown coefficient $=0.73)^{14}$ taps how much respondents trust in two representatives of the industrial capitalist system: "oil and gas companies" and "the US business community." Trust in forces of reflexivity (Spearman-Brown coefficient $=0.74$ ) taps how much respondents trust in two forces of reflexivity: "environmental groups" and "the academic/ scientific community."

Identification with the environmental movement is measured with the following item: "As the term is generally used today, do you consider yourself to be an environmentalist?" Self-identified environmentalist is coded "2" for "yes, active environmentalist," " 1 " for "yes, passive environmentalist," and " 0 " for "no, not an environmentalist" or "prefer not to answer." Approximately $12.4 \%$ of the pooled sample identifies as an active environmentalist, $36.4 \%$ as a passive environmentalist, and $51.2 \%$ as not an environmentalist.

Party identification is measured with a set of two dummy variables with "Independent" as the reference category. ${ }^{15}$ Republican includes those respondents who identify as "lean Republican" to "strong Republican," and Democrat includes those respondents who identify as "lean Democrat" to "strong Democrat." The small percentages of respondents who answered "other" or "prefer not to answer" were coded as Independent. The 3.5\% of the pooled sample who identified as "Libertarian" were dropped from analyses. ${ }^{16}$ This resulted in the following percentages in the pooled sample: $32.0 \%$ Republican, $27.7 \%$ Independent, and $40.3 \%$ Democrat.

Three indicators measure energy-related policy preferences. The single-item indicator, support for new EPA rules restricting emissions at coal-fired power plants, measures whether respondents "oppose" (-1), "support" (1), or are "not sure" (0) about the new EPA rules. The single-item indicator, support for development of renewable technologies, measures whether respondents believe ("no" = 0; "yes" = 1) the federal government should focus on developing

13 The survey used "use energy more efficiently" in Wave 2, "conserve energy" in Wave 3, and both "use energy more efficiently" and "conserve energy" in a split-half design in Waves 4-7. Thus, the survey did not ask about trust in general or about trust specifically on the topic of climate change but trust on the less politicized topic of energy conservation and efficiency.

14 Reliability analysis for the first two indexes was performed with the Spearman-Brown coefficient, which is more appropriate than is Cronbach's alpha when only two items are available (e.g., Eisinga, Grotenhuis, \& Pelzer, 2013).

15 Waves 2-7 did not include a survey item to measure political ideology.

16 In additional analyses, I retained those respondents identifying as Libertarian and included them in the Republican grouping. Analyses using this revised party identification indicator produced results closely similar to those presented here. 
renewable technologies. A composite index, support for subsidies for renewable energies (Cronbach's Alpha $=0.83$ ), measures whether respondents believe ("no" = 0; "yes" = 1) the federal government should subsidize renewable technologies, energy efficiency, and electric vehicles.

Two indicators measure energy-related voting intentions. A composite index, intention to vote for a presidential candidate who supports fossil fuels development (Cronbach's Alpha = 0.79), measures how more or less likely ("much less likely" = 1 to "much more likely" = 5) respondents would be to vote for a presidential candidate who supports expanding offshore oil development in the Gulf Coast of Mexico, expanding domestic natural gas development, and approving the construction of the XL Keystone pipeline to transport oil from Canada to the Gulf Coast. Another composite index, intention to vote for a presidential candidate who supports renewable energy development (Cronbach's Alpha = 0.82), measures how more or less likely ("much less likely" = 1 to "much more likely" = 5) respondents would be to vote for a presidential candidate who supports expanding financial incentives for companies engaged in renewable technologies, requiring utilities to get a certain percentage of electricity from renewable sources, and increasing funding for scientific and university research on new energy technologies.

Finally, two indicators measure energy conservation behavioral intentions. A composite index, intention to adopt energy conservation technologies (Cronbach's Alpha $=0.83$ ), measures how likely ("not at all likely" $=1$ to "very likely" $=7$ and "do this currently/have done it already" = 8) that respondents would do the following within the next five years: own a hybrid vehicle, own a fully electric vehicle, own a vehicle that runs on natural gas, use "smart meter" technology allowing for better management of household electricity demand, and install solar panels at your home. Another composite index, intention to perform household energy conservation behaviors (Cronbach's Alpha $=0.74$ ), measures how likely ("not at all likely" = 1 to "very likely" = 7 and "do this currently/ have done it already" = 8) that respondents would do the following within the next five years: purchase energy efficient light bulbs, improve insulation in your home, purchase an energy efficient appliance, and have a home energy audit performed.

Ten demographic and social variables are employed as controls in the multivariate statistical analyses. Gender ("female" =1) and race ("white" =1) 17 are measured with dummy variables. Age varies from "18-24" $=1$ to "75 or over" $=11$. Socioeconomic status is measured with three variables: education ("less than high school diploma" = 1 to "post-graduate degree" = 5), income ("less than

17 For more direct comparability with prior studies of climate change skepticism, this category includes both non-Latino Whites and Latino Whites. 
$\$ 20,000 "=1$ to $" \$ 200,000$ or more" $=8$ ) and employed ("not employed" $=0$, "employed part- or full-time" = 1). ${ }^{18}$ Religiosity ranges between "not religious at all" = 1 to "very religious" $=4$. Whether or not a respondent was the parent of a minor child ("parent" = 1) was measured with a dummy variable. Finally, place of residence was measured with two dummy variables ("urban" and "rural") using "suburban" as the reference category.

\section{Results and discussion}

\section{The influence of Anti-Reflexivity Thesis variables on climate change skepticism}

Since both climate change skepticism measures are dichotomous, I used logistic regression analysis to test the five hypotheses derived from the Anti-Reflexivity Thesis. Table 3 presents the estimated odds ratios of key theoretical variables from logistic regression models predicting trend and attribution skepticism in the US general public. An odds ratio greater than 1 means that a predictor increases the odds of being a climate change skeptic rather than not being one, and an odds ratio lesser than 1 means that a predictor decreases the odds of being a skeptic rather than not being one.

As expected by the Anti-Reflexivity Thesis, trust in groups representing the industrial capitalist system increases the likelihood of skepticism of the reality and human cause of climate change (supporting $\mathrm{Hl}$ ). That is, trusting oil and gas companies and the business community on the topic of energy increases the likelihood of trend and attribution skepticism. This effect endures even when accounting for the effects of other key theoretical predictors and the demographic and social controls.

Further, compared to Independents, Republicans are more likely to be trend and attribution skeptics (supporting H2). This effect (a positive relationship between conservative party identification and climate change skepticism) is consistent with most empirical work in the US (e.g., Hamilton, 2012; McCright \& Dunlap, 2011a) and beyond (e.g., Leviston \& Walker, 2012; Poortinga et al., 2011).

18 The "not employed" category includes full-time homemakers, students, retirees, and the temporarily unemployed. 
Table 3: Estimated odds ratios from logistic regression models predicting climate change skepticism in the US general public

\begin{tabular}{|c|c|c|}
\hline Predictors & $\begin{array}{c}\text { Trend Skepticism } \\
\text { Model } 1\end{array}$ & $\begin{array}{c}\text { Attribution Skepticism } \\
\text { Model } 2\end{array}$ \\
\hline \multicolumn{3}{|l|}{ Anti-Reflexivity Variables } \\
\hline Trust in industrial capitalist groups & $1.63^{\star \star \star}$ & $1.47^{\star \star \star}$ \\
\hline Trust in forces of reflexivity & $0.38^{\star \star \star}$ & $0.58^{\star \star \star}$ \\
\hline Self-identified environmentalist & $0.60^{\star \star *}$ & $0.72^{\star \star \star}$ \\
\hline Republican & $2.29^{\star \star \star}$ & $1.45^{\star \star \star}$ \\
\hline Democrat & $0.54^{\star \star *}$ & 0.87 \\
\hline \multicolumn{3}{|c|}{ Demographic and Social Characteristics } \\
\hline Female & $0.78^{\star \star \star}$ & $0.88^{*}$ \\
\hline Age & 1.00 & 1.02 \\
\hline White & $1.62^{\star \star \star}$ & $1.45^{\star \star \star}$ \\
\hline Education & 0.95 & 1.02 \\
\hline Income & 1.02 & 1.01 \\
\hline Employed & 0.96 & 1.04 \\
\hline Religiosity & $1.28^{\star \star \star}$ & 1.01 \\
\hline Parent & $0.85^{\star}$ & 0.94 \\
\hline Urban & 0.99 & $0.76^{\star \star \star}$ \\
\hline Rural & 0.96 & 1.07 \\
\hline \multicolumn{3}{|l|}{ Survey Waves } \\
\hline Wave 3 & $0.67^{\star \star \star}$ & \\
\hline Wave 4 & $0.69^{\star \star \star}$ & 0.96 \\
\hline Wave 5 & $0.72^{\star \star \star}$ & 0.88 \\
\hline Wave 6 & 0.87 & $0.76^{\star \star}$ \\
\hline Wave 7 & $0.76^{\star \star}$ & $0.68^{\star \star \star}$ \\
\hline Nagelkerke $\mathrm{R}^{2}$ & 0.39 & 0.13 \\
\hline $\mathrm{N}$ & 12,471 & 7,265 \\
\hline
\end{tabular}

Notes: The reference category for political party identification is "Independent." The reference category for place of residence is "Suburban." The reference category for survey wave in Model 1 is Wave 2, and the reference category for survey wave in Model 2 is Wave 3.

${ }^{*} p<.05^{* \star} p<.01{ }^{* \star *} p<.001$

Also as expected by the Anti-Reflexivity Thesis, trust in environmental groups and the scientific community on the topic of energy decreases the likelihood of trend and attribution skepticism (supporting H3). Further, identifying with the environmental movement decreases the likelihood of both dimensions of skepticism examined here (supporting H4). This effect (an inverse relationship 
between environmental identity and climate change skepticism) confirms the findings of several earlier studies in the US (e.g., Feldman et al., 2012; Heath \& Gifford, 2006; McCright \& Dunlap, 2011a) and abroad (e.g., Engels et al., 2013; Whitmarsh, 2011). Hypothesis 5 receives partial support. Democrats are less likely than are Independents to be trend skeptics, but there is no statistically significant difference between Independents and Democrats on attribution skepticism.

Only two of the demographic and social controls have a consistent effect on both dimensions of skepticism. Briefly, males and whites are more likely than are their female and non-white counterparts to be trend and attribution skeptics, confirming an earlier finding (McCright \& Dunlap, 201 la). Similar to what most prior studies find, the remaining demographic and social variables do not have consistent effects on climate change skepticism.

\section{The influence of climate change skepticism on energy-related policy preferences, voting intentions, and behavioral intentions}

Other than Engel et al.'s (2013) study of German adults, scholars have yet to examine how climate change skepticism is related to energy-related attitudes and behaviors. I investigate this here as a step to better understand the extent to which climate change skepticism in the US general public matters more broadly. The tables below present the effects of trend and attribution skepticism on citizens' energy-related policy preferences (Tables 4 and 5), voting intentions (Table 6), and behavioral intentions (Table 7) not only controlling for demographic and social characteristics and the survey wave but also the key Anti-Reflexivity Thesis variables discussed above. Except for Models 5 and 6 in Table 5 (which use logistic regression to predict a dichotomous outcome variable), the models in these tables employ ordinary least squares (OLS) regression.

Briefly, both trend and attribution skepticism lead to greater opposition to policies shifting our economy away from its fossil fuels base. Compared to their non-skeptical counterparts, trend and attribution skeptics are less supportive of policies aimed at directly reducing greenhouse gas emissions (Table 4) and at developing and subsidizing renewable energy technologies (Table 5). These results complement those of Engels et al. (2013), who find that climate change skepticism correlates with greater support for fossil fuel energy sources (e.g., coal, oil) and with lesser support for renewable energy sources (e.g., wind, solar, hydro). 
Table 4: Coefficients (and standard errors) from OLS regression models predicting support for new EPA rules restricting emissions at coal-fired power plants in the US general public

\begin{tabular}{|c|c|c|}
\hline \multirow[b]{2}{*}{ Predictors } & \multicolumn{2}{|c|}{$\begin{array}{l}\text { Support for New EPA Rules Restricting } \\
\text { Emissions at Coal-Fired Power Plants }\end{array}$} \\
\hline & Model 3 & Model 4 \\
\hline \multicolumn{3}{|l|}{ Anti-Reflexivity Indicators } \\
\hline Trend skeptic & $-0.38(.05)^{\star \star \star}$ & \\
\hline Attribution skeptic & & $-0.22(0.04)^{\star \star \star}$ \\
\hline Trust in industrial capitalist groups & $-0.13(0.02)^{\star \star \star}$ & $-0.08(0.02)^{\star \star \star}$ \\
\hline Trust in forces of reflexivity & $0.18(0.02)^{\star \star \star}$ & $0.15(0.02)^{\star \star \star}$ \\
\hline Self-identified environmentalist & $0.14(0.02)^{\star \star \star}$ & $0.11(0.03)^{\star \star \star}$ \\
\hline Republican & $-0.09(0.04)^{\star}$ & $-0.07(0.05)$ \\
\hline Democrat & $0.14(0.04)^{\star \star \star}$ & $0.14(0.04)^{\star \star}$ \\
\hline \multicolumn{3}{|c|}{ Demographic and Social Characteristics } \\
\hline Female & $-0.03(0.03)$ & $-0.10(0.03)^{\star \star}$ \\
\hline Age & $0.00(0.01)$ & $0.01(0.01)$ \\
\hline White & $-0.04(0.04)$ & $-0.04(0.04)$ \\
\hline Education & $0.07(0.02)^{\star \star \star}$ & $0.08(0.02)^{\star \star \star}$ \\
\hline Income & $-0.01(0.01)$ & $-0.00(0.01)$ \\
\hline Employed & $0.03(0.03)$ & $0.04(0.04)$ \\
\hline Religiosity & $-0.03(0.02)^{*}$ & $-0.03(0.02)$ \\
\hline Parent & $0.03(0.03)$ & $0.04(0.04)$ \\
\hline Urban & $0.02(0.04)$ & $0.02(0.04)$ \\
\hline Rural & $-0.11(0.04)^{\star *}$ & $-0.13(0.04)^{\star \star}$ \\
\hline Constant & $-0.20(0.10)^{*}$ & $-0.19(0.11)$ \\
\hline Adjusted $\mathrm{R}^{2}$ & 0.31 & 0.18 \\
\hline $\mathrm{N}$ & 2,029 & 1,468 \\
\hline
\end{tabular}

Notes: The reference category for political party identification is "Independent." The reference category for place of residence is "Suburban."

${ }^{*} p<.05{ }^{* *} p<.01{ }^{* * *} p<.001$ 


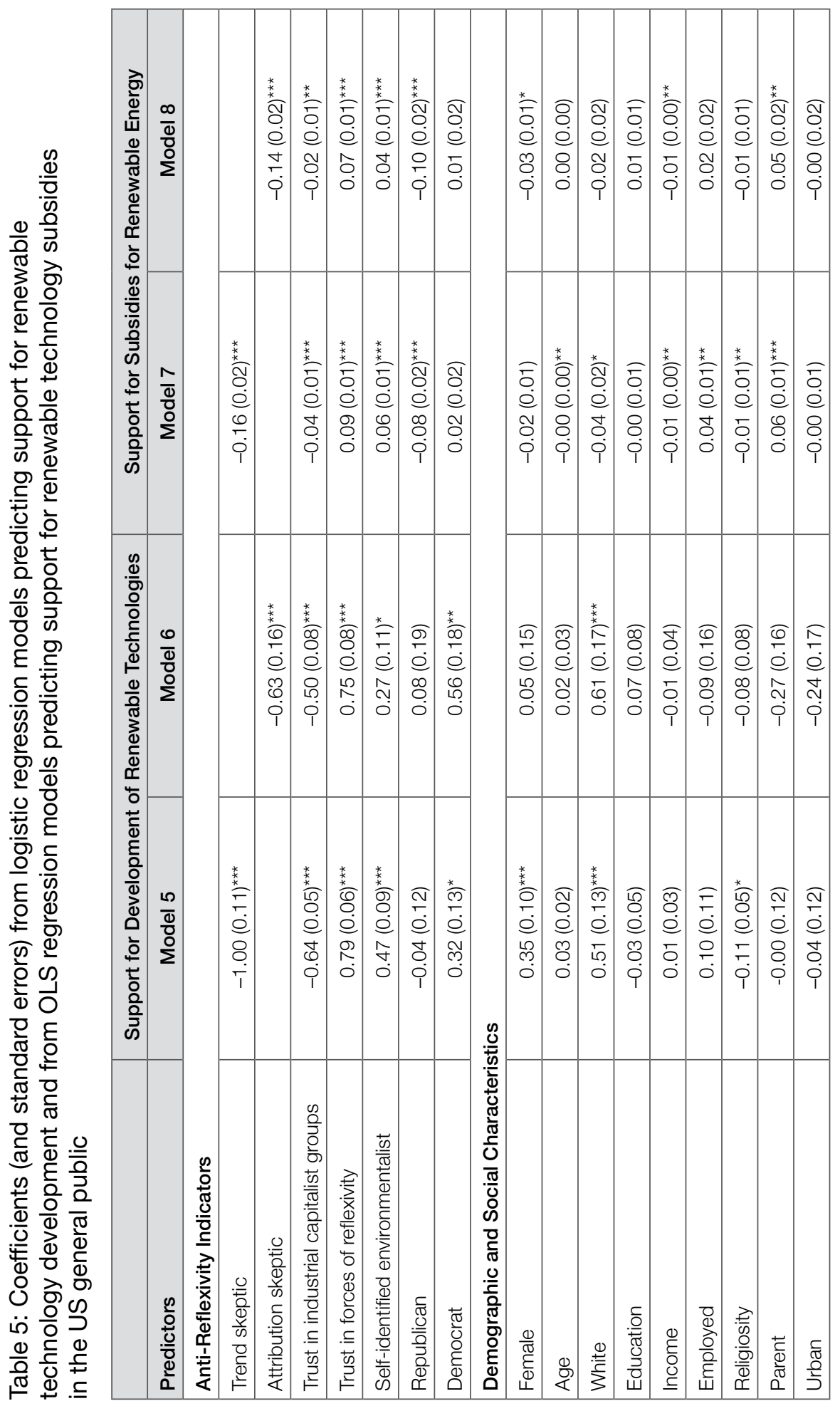


Human Ecology Review, Volume 22, Number 2, 2016

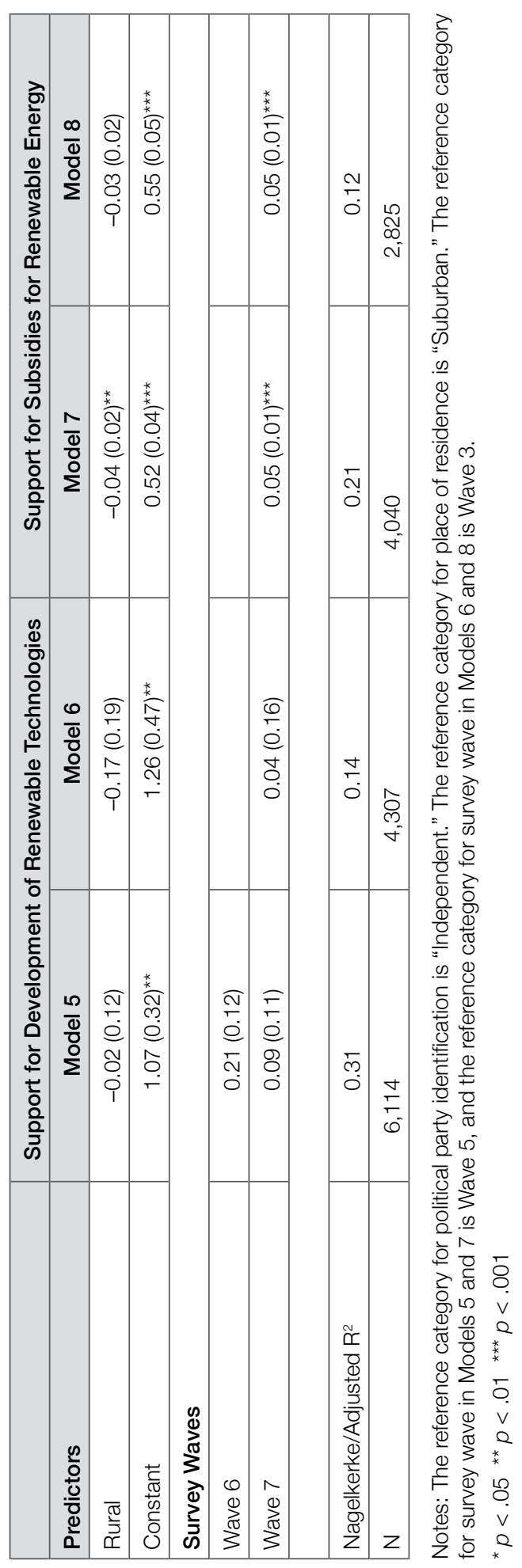


Also, compared to their non-skeptical counterparts, trend and attribution skeptics are more likely to vote for a presidential candidate who supports fossil fuels development and less likely to vote for one who supports renewable energy development (Table 6). Further, compared to non-skeptics, trend and attribution skeptics are less likely to adopt energy conservation technologies and perform household energy conservation behaviors (Table 7). Briefly then, these results provide compelling evidence that climate change skepticism has an influence on environmentally consequential decisions beyond those directly related to the politicized issue of climate change. Indeed, even when controlling for the effects of other key predictors and characteristics, climate change skepticism is associated with attitudinal opposition to shifting away from fossil fuels and behavioral opposition to energy efficiency and conservation.

Several of the key Anti-Reflexivity Thesis variables also have reasonably strong effects on energy-related policy preferences, voting intentions, and behavioral intentions. For each of the seven energy-related outcome variables, trust in forces of reflexivity and identification with the environmental movement predict attitudes and behavioral intentions representing support for shifting from fossil fuels to renewable energy technologies and increasing energy conservation. Further, trust in representatives of the industrial capitalism system predicts policy preferences and voting intentions to defend the existing fossil fuel-based economic system and oppose new regulations. ${ }^{19}$

Compared to these variables, the party identification indicators have less consistent effects across the models. Compared to Independents, Republicans are less supportive of subsidies for renewable technologies and are more likely to vote for a Presidential candidate who supports fossil fuels development. Also compared to Independents, Democrats are more supportive of the new EPA rules restricting emissions at coal-fired power plants, more supportive of the development of renewable technologies, and more likely to vote for a Presidential candidate who supports renewable energy development. Neither party identification indicator is a consistent predictor of energy conservation behavioral intentions.

19 While trust in industrial capitalist groups has no influence on intentions to perform household energy conservation behaviors, it does have a positive effect on intentions to adopt energy conservation technologies. 


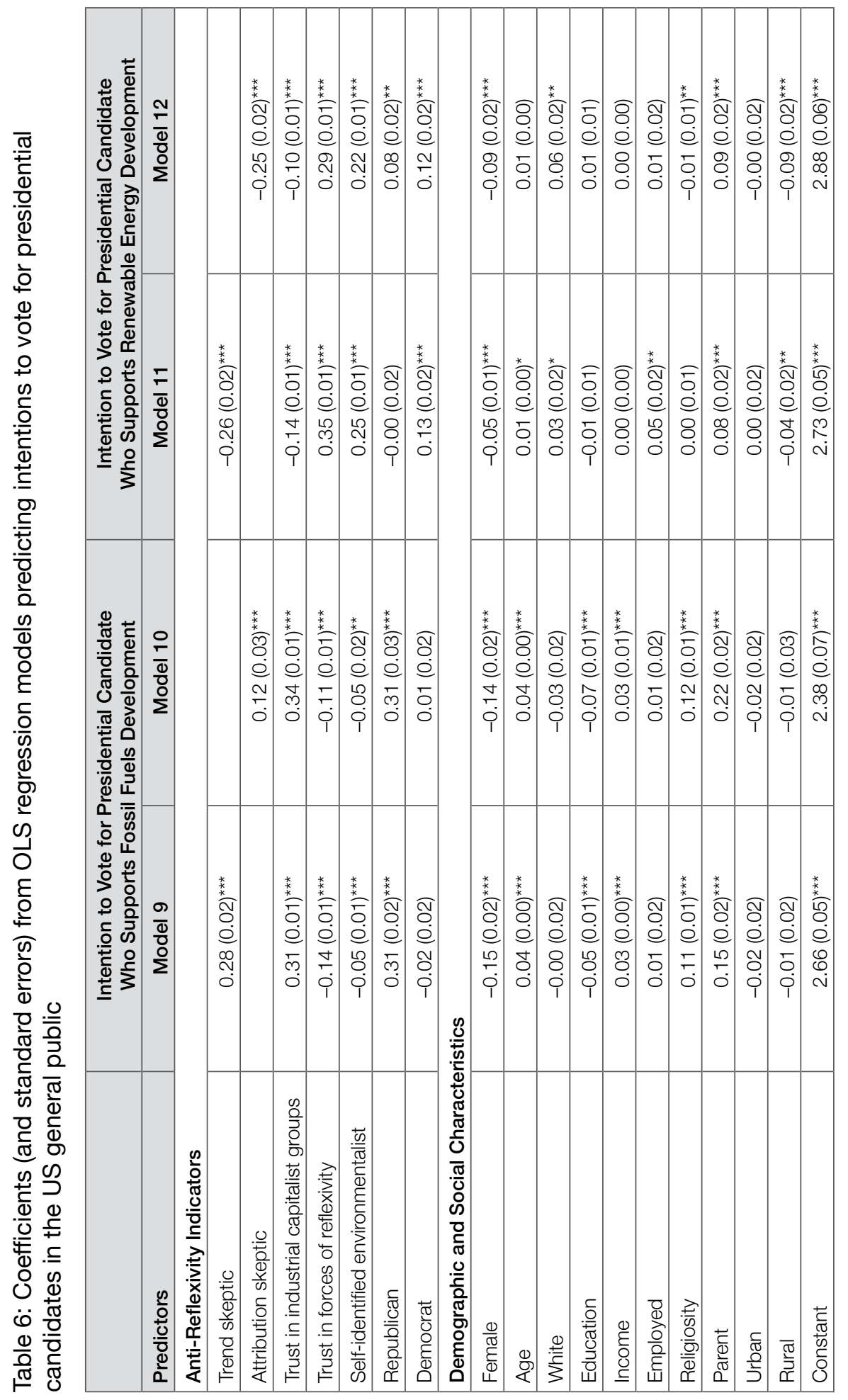




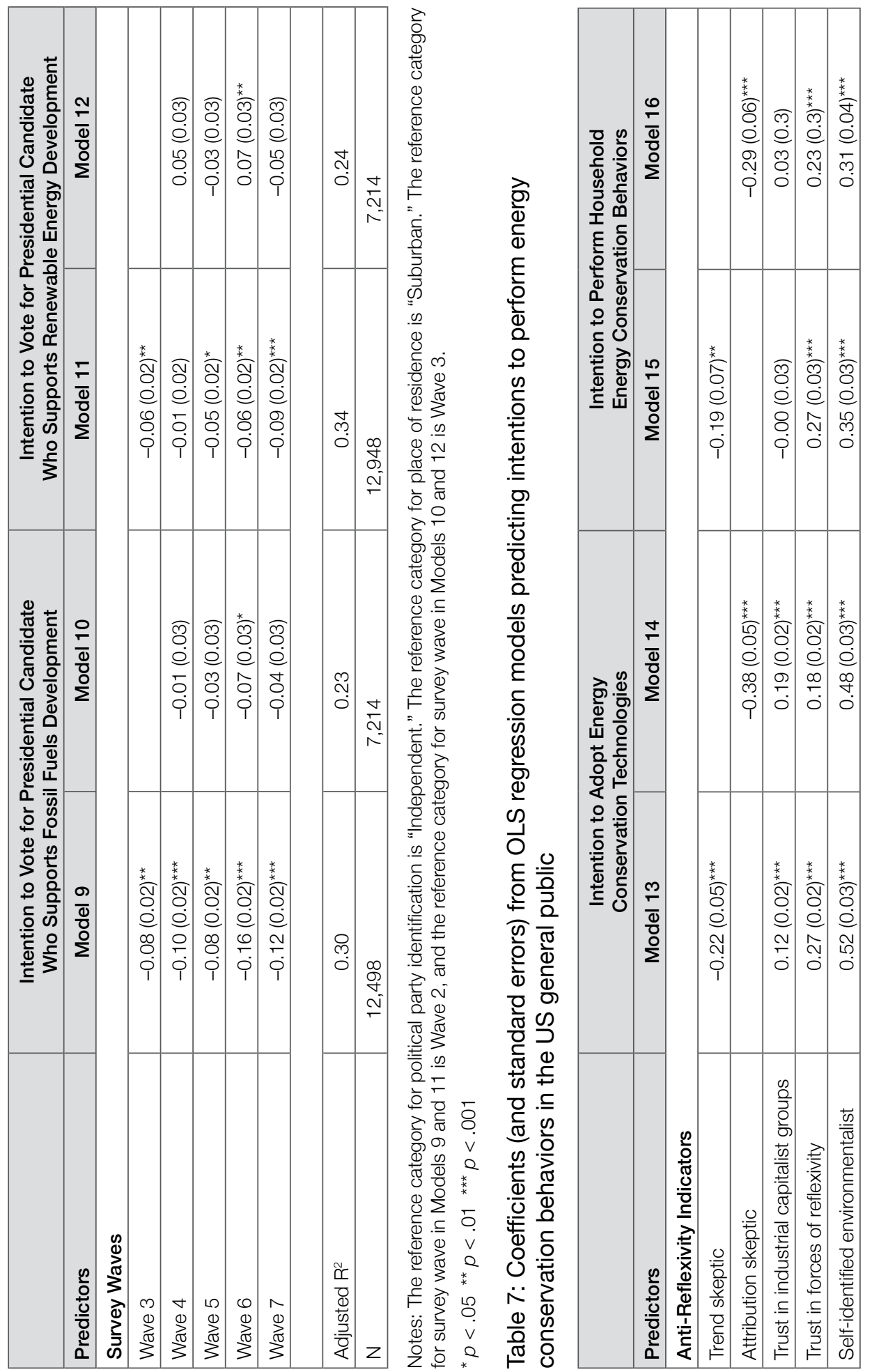




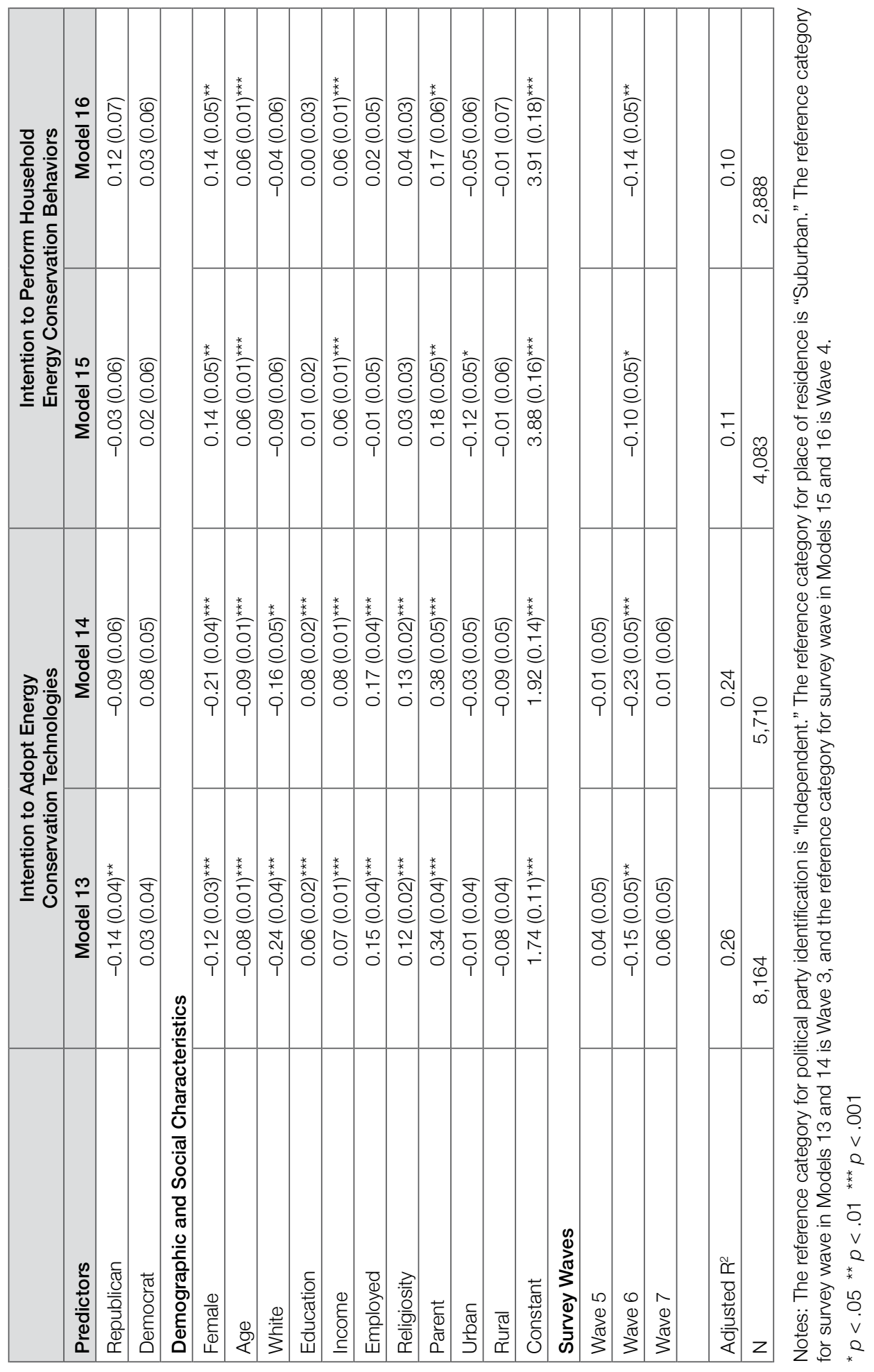


For the most part, respondents' demographic and social characteristics account for little of the adjusted $\mathrm{R}^{2}$ values across the models in Tables 4 to 7 . Not surprisingly, few of these control variables have consistent effects across the models. Education has a positive effect and living in a rural area (compared to living in a suburban area) has a negative effect on support for the EPA's new rules restricting emissions from coal-fired power plants (Table 4). While whites report greater support for the development of renewable technologies than do non-whites, parents and less-wealthy adults report greater support for subsidies for renewable technologies than do non-parents and wealthier adults (Table 5).

Both males and parents are more likely than are females and non-parents to vote for candidates who support the development of either fossil fuels or renewable energy sources (Table 6). While older, lesser educated, wealthier, and more religious adults are more likely than are their respective counterparts to vote for a presidential candidate who supports fossil fuels development, non-Whites and rural residents are less likely than are their respective counterparts to vote for a presidential candidate who supports renewable energy development. While males and older adults are more likely than are females and younger adults to purchase or adopt energy conservation technologies, the reverse is true for performing household energy conservation behaviors (Table 7). Also, parents and wealthier adults are more likely than are non-parents and less-wealthy adults to adopt energy conservation technologies and perform household energy conservation behaviors. Finally, non-Whites, the highly educated, employed adults, and more religious adults are more likely than are their respective counterparts to adopt energy conservation technologies.

\section{Conclusion}

While the Anti-Reflexivity Thesis has been employed primarily to explain organized climate change denial (e.g., McCright \& Dunlap, 2010), this study demonstrates that it also provides theoretical purchase for explaining patterns of climate change skepticism within the general public. Briefly, identification with or trust in groups representing or defending the industrial capitalist system increases the likelihood of skepticism of the reality and human cause of climate change. These effects suggest that anti-reflexivity more generally-beyond that which is institutionalized within and promoted by the politically conservative Republican party-likely impacts climate change skepticism in the general public. Also, identification with or trust in groups representing or defending forces of reflexivity decreases the likelihood of trend and attribution skepticism. 
Further, this study finds that both trend and attribution skepticism are related to citizens' energy-related policy preferences, voting intentions, and behavioral intentions in ways consistent with the Anti-Reflexivity Thesis. That is, trend and attribution skeptics report attitudes and behavioral intentions that generally support the existing fossil fuels-based industrial capitalist system and oppose regulatory interventions to reform the system either slightly or substantially. These results demonstrate that climate change skepticism influences environmentally consequential decisions beyond those directly related to the politicized issue of climate change.

The literature on climate change skepticism is still developing, even as some robust patterns have emerged. Future survey research should continue examining predictors of climate change skepticism in the general publics of countries around the world. Such work may employ the Anti-Reflexivity Thesis, especially including measures of key components of the argument. For instance, finding that trust in and identification with forces of anti-reflexivity influence climate change skepticism independent of the effect of political orientation in the US suggests that these variables may be as or more efficacious in countries where climate change is less politicized and skepticism is less aligned with political orientation. Future work also should aim to employ more sophisticated techniques (e.g., structural equation modeling) to model both direct and indirect effects in path analyses. This research also may incorporate other theoretically relevant predictors (e.g., values orientations) that are likely to influence climate change skepticism.

Scholars also should conduct experimental work to investigate the types of messages, frames, messengers, and modes of delivery that may amplify or reduce climate change skepticism. A few such experimental studies have been conducted already. While some suggest there is cause for optimism regarding efforts at decreasing skepticism (e.g., Hornsey et al., 2015), others are less sanguine (e.g., McCright et al., 2016). Nevertheless, some recent developments - such as a growing number of prominent US Republicans and conservative leaders publicly accepting the science of climate change and advocating climate action (e.g., George Schultz, Bob Inglis, etc.) and Pope Francis's June 2015 encyclical on climate change - suggest messages and messengers worthy of experimental testing.

\section{References}

Beck, U. (1992). Risk Society. London: Sage.

Boussalis, C., \& Coan, T. G. (2016). Text-mining the signals of climate change doubt. Global Environmental Change, 36, 89-100. 
Brulle, R. J. (2014). Institutionalizing delay: Foundation funding and the creation of U.S. climate change counter-movement organizations. Climatic Change, 122, 681-694.

Campbell, T. H., \& Kay, A. C. (2014). Solution aversion: On the relation between ideology and motivated disbelief. Journal of Personality and Social Psychology, $107,809-824$.

Capstick, S. B., \& Pidgeon, N. F. (2014). What is climate change skepticism?: Examination of the concept using a mixed methods study of the UK public. Global Environmental Change, 24, 389-401.

Cho, C. H., Martens, M. J., Kim, H., \& Rodrigue, M. (2011). Astroturfing global warming: It isn't always greener on the other side of the fence. Journal of Business Ethics, 104, 571-587.

Clements, B. (2012). Exploring public opinion on the issue of climate change in Britain. British Politics, 7, 183-202.

Dunlap, R. E., \& Jacques, P. J. (2013). Climate change denial books and conservative think tanks: Exploring the connection. American Behavioral Scientist, 57, 699-731.

Dunlap, R. E., \& McCright, A. M. (2010). Climate change denial: Sources, actors, and strategies. In C. Lever-Tracy (Ed.), Routledge Handbook of Climate Change and Society (pp. 240-259). New York: Routledge Press.

Dunlap, R. E., \& McCright, A. M. (2011). Organized climate change denial. In J. Dryzek, R. Norgaard, \& D. Schlosberg (Eds.), Oxford Handbook of Climate Change and Society (pp. 144-160). Cambridge: Oxford University Press.

Dunlap, R. E., \& McCright, A. M. (2015). Challenging climate change: The denial countermovement. In R. E. Dunlap \& R. J. Brulle (Eds.), Sociological Perspectives on Global Climate Change (pp. 300-332). New York: Oxford University Press.

Eisinga, R., Grotenhius, M. T., \& Pelzer, B. (2013). The Reliability of a twoitem scale: Pearson, Cronbach, or Spearman-Brown? International Journal of Public Health, 58, 637-642.

Engels, A., Hüther, O., Schäfer, M., \& Held, H. (2013). Public climatechange skepticism, energy preferences, and political participation. Global Environmental Change, 23, 1018-1027.

Evans, J. H., \& Feng, J. (2013). Conservative Protestantism and skepticism of scientists studying climate change. Climatic Change, 121, 595-608. 
Farrell, J. (2016a). Corporate funding and ideological polarization about climate change. Proceedings of the National Academy of Sciences, 113, 1, 92-97.

Farrell, J. (2016b). Network structure and influence of the climate change counter-movement. Nature Climate Change, 6, 370-374.

Feldman, L., Maibach, E. W., Roser-Renouf, C, \& Leiserowitz, A. (2012). Climate on cable: The nature and impact of global warming coverage on Fox News, CNN, and MSNBC. International Journal of Press/Politics, 17, 3-31.

Foster, J. B., Clark, B., \& York, R. (2011). The Ecological Rift: Capitalism's War on Earth. New York: Monthly Review Press.

Freudenburg, W. R., Gramling, R., \& Davidson, D. J. (2008). Scientific certainty argumentation methods (SCAMs): Science and the politics of doubt. Sociological Inquiry, 78, 2-38.

Giddens, A. (1990). The Consequences of Modernity. Oxford: Polity Press.

Gleeson, B. (2000). Reflexive modernization. International Planning Studies, 5, 117-135.

Gould, K. A. (2015). Slowing the nanotechnology treadmill: Impact science versus production science for sustainable technological development. Environmental Sociology, 1(3), 143-151.

Häkkinen, K., \& Akrami, N. (2014). Ideology and climate change denial. Personality and Individual Differences, 70, 62-65.

Hamilton, L. C. (2012). Did the Arctic ice recover?: Demographics of true and false climate facts. Weather, Climate, and Society, 4, 236-249.

Heath, Y., \& Gifford, R. (2006). Free-market ideology and environmental degradation: The case of belief in global climate change. Environment and Behavior, 38, 48-71.

Hmielowski, J. D., Feldman, L., Myers, T. A., Leiserowitz, A., \& Maibach, E. (2014). An Attack on science?: Media use, trust in scientists, and perceptions of global warming. Public Understanding of Science, 23, 866-883.

Hobson, K., \& Niemeyer, S. (2013). 'What skeptics believe': The Effects of information and deliberation on climate change skepticism. Public Understanding of Science, 22, 396-412. 
Hornsey, M. J., Fielding, K. S., McStay, R., Reser, J. P., \& Bradley, G. L. (2015). Are people high in skepticism about anthropogenic climate change necessarily resistant to influence?: Some cause for optimism. Environment and Behavior. doi: $10.1177 / 0013916515574085$.

Jacques, P. (2006). The Rearguard of modernity: Environmental skepticism as a struggle of citizenship. Global Environmental Politics, 6, 76-101.

Lahsen, M. (2008). Experiences of modernity in the greenhouse. Global Environmental Change, 18, 204-219.

Layzer, J. (2007). Deep Freeze. In M. E. Kraft \& S. Kamieniecki (Eds.), Business and Environmental Policy (pp. 93-125). Cambridge, MA: MIT Press.

Leiserowitz, A. A., Maibach, E. W., Roser-Renouf, C., Smith, N., \& Dawson, E. (2012). Climategate, public opinion, and the loss of trust. American Behavioral Scientist, 57, 818-837.

Leviston, Z., \& Walker, I. (2012). Beliefs and denials about climate change: An Australian perspective. Ecopsychology, 4, 277-285.

Leviston, Z., Walker, I., \& Morwinski, S. (2013). Your opinion on climate change might not be as common as you think. Nature Climate Change, 3, 334-337.

Lewandowsky S., Gignac, G. E., \& Oberauer, K. (2013). The Role of conspiracist ideation and worldviews in predicting rejection of science. PLOS ONE, 8, e75637.

Lewandowsky, S., Oberauer, K., \& Gignac, G. E. (2013). NASA faked the Moon landing - therefore (climate) science is a hoax: An anatomy of the motivated rejection of science. Psychological Science, 24, 622-633.

Lo, A. Y. (2014). The Right to doubt: Climate change skepticism and asserted rights to private property. Environmental Politics, 23, 549-569.

McCright, A. M. (2007). Dealing with climate change contrarians. In S. C. Moser \& L. Dilling (Eds.), Creating a Climate for Change: Communicating Climate Change and Facilitating Social Change (pp. 200-212). New York: Cambridge University Press.

McCright, A. M., Charters, M., Dentzman, K., \& Dietz, T. 2016. Examining the effectiveness of climate change frames in the face of a denialist counterframe. Topics in Cognitive Science, 8(1), 76-97.

McCright, A. M., Dentzman, K., Charters, M., \& Dietz, T. (2013). The Influence of political ideology on trust in science. Environmental Research Letters, 8,044029 . 
McCright, A. M., \& Dunlap, R. E. (2000). Challenging global warming as a social problem: An analysis of the conservative movement's counter claims. Social Problems, 47, 499-522.

McCright, A. M., \& Dunlap, R. E. (2003). Defeating Kyoto: The conservative movement's impact on U.S. climate change policy. Social Problems, 50, 348-373.

McCright, A. M., \& Dunlap, R. E. (2010). Anti-Reflexivity: The American conservative movement's success in undermining climate science and policy. Theory, Culture, and Society, 27, 100-133.

McCright, A. M., \& Dunlap, R. E. (2011a). Cool dudes: The Denial of climate change among conservative white males in the United States. Global Environmental Change, 21, 1163-1172.

McCright, A. M., \& Dunlap, R. E. (2011b). The Politicization of climate change and polarization in the American public's views of global warming, 2001-2010. The Sociological Quarterly, 52, 155-194.

McCright, A. M., Dunlap, R. E., \& Xiao, C. (2013). Perceived scientific agreement and support for government action on climate change in the USA. Climatic Change, 119, 511-518.

McCright, A. M., Xiao, C., \& Dunlap, R. E. (2014). Political polarization on support for government spending on environmental protection in the USA, 1974-2012. Social Science Research, 48, 251-260.

Merton, R. K. (1938). Science and the social order. Philosophy of Science, 5, $321-337$.

Mol, A. P. J. (2000). The Environmental movement in an era of ecological modernization. Geoforum, 32, 45-56.

Oreskes, N., \& Conway, E. M. (2010). Merchants of Doubt. New York: Bloomsbury Press.

Poortinga, W., Spence, A., Whitmarsh, L., Capstick, S., \& Pidgeon, N. F. (2011). Uncertain climate: An Investigation into public skepticism about anthropogenic climate change. Global Environmental Change, 21, 1015-1024.

Rahmstorf, S. (2004). The Climate skeptics. In Munich Re (Ed.), Weather Catastrophes and Climate Change (pp. 76-83). Munich, Germany: Munich Re.

Rosa, E. A., Renn, O., \& McCright, A. M. (2014). The Risk Society Revisited: Social Theory and Governance. Philadelphia, PA: Temple University Press. 
Schnaiberg, A. (1980). The Environment: From Surplus to Scarcity. New York: Oxford University Press.

Smith, N., \& Leiserowitz, A. (2012). The Rise of global warming skepticism: Exploring affective image associations in the United States over time. Risk Analysis, 32, 1021-1032.

Whitmarsh, L. (2011). Skepticism and uncertainty about climate change: Dimensions, determinants and change over time. Global Environmental Change, 21, 690-700. 
This text is taken from Human Ecology Review, Volume 22, Number 2, 2016, published 2016 by ANU Press, The Australian National University, Canberra, Australia. 